\title{
Epidemiological link between exposure to poultry and all influenza A(H7N9) confirmed cases in Huzhou city, China, March to May 2013
}

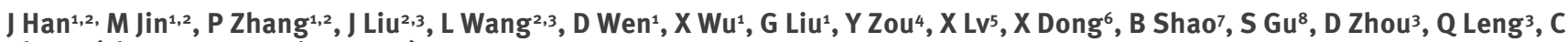

Zhang (zhangcy1999@ips.ac.cn) ${ }^{3}$, K Lan $^{3}$

1. Huzhou Center for Disease Control and Prevention, Huzhou, Zhejiang China

2. These authors contributed equally to this work

3. Institut Pasteur of Shanghai, Chinese Academy of Sciences, Shanghai, China

4. Nanxun District Center for Disease Control and Prevention, Huzhou, Zhejiang, China

5. Wuxing District Center for Disease Control and Prevention, Huzhou, Zhejiang, China

6. Deqing County Center for Disease Control and Prevention, Huzhou, Zhejiang, China

7. Changxing County Center for Disease Control and Prevention, Huzhou, Zhejiang, China

8. Anji County Center for Disease Control and Prevention, Huzhou, Zhejiang, China

Citation style for this article:

Han J, Jin M, Zhang P, Liu J, Wang L, Wen D, Wu X, Liu G, Zou Y, Lv X, Dong X, Shao B, Gu S, Zhou D, Leng Q, Zhang C, Lan K. Epidemiological link between exposure to poultry and all influenza A(H7N9) confirmed cases in Huzhou city, China, March to May 2013. Euro Surveill. 2013;18(20):pii=20481. Available online: http://www. eurosurveillance.org/ViewArticle. .aspx?Articleld=20481

Article submitted on 05 May 2013 / published on 16 May 2013

We analysed the association between influenza $\mathrm{A}\left(\mathrm{H}_{7} \mathrm{~N} 9\right)$ confirmed cases and exposure to poultry in Huzhou city, China. All cases $(n=12)$ had a history of direct exposure to poultry or live poultry markets. We detected $\mathrm{A}\left(\mathrm{H}_{7} \mathrm{~N} 9\right)$-positive poultry samples from each site that was epidemiologically associated with cases. None of the cases' close contacts tested positive. After closure of the markets, no new cases were identified, suggesting an epidemiological link between poultry exposure and $\mathrm{A}\left(\mathrm{H}_{7} \mathrm{N9}\right)$ virus infection.

\section{Background}

Since February 2013, a novel avian influenza $A\left(\mathrm{H}_{7} \mathrm{~N}_{9}\right)$ virus has led to an outbreak in the Yangtze River Delta Region and elsewhere in China [1,2]. As of 10 May 2013, it has resulted in 129 cases, including 31 deaths. Sporadic human infections by several $\mathrm{H}_{7}$ subtypes of influenza $A$ viruses (e.g. $\mathrm{H}_{7} \mathrm{~N}_{2}, \mathrm{H}_{7} \mathrm{~N}_{3}$ and $\mathrm{H}_{7} \mathrm{~N}_{7}$ ) had been reported previously in several countries in Europe and North America [3]. Apart from an influenza $A\left(\mathrm{H}_{7} \mathrm{~N}_{7}\right)$ outbreak in the Netherlands in 2003, infections with these $\mathrm{H}_{7}$ subtypes usually result in a mild, self-limiting illness [3]. In contrast, in the current influenza A $\left(\mathrm{H}_{7} \mathrm{~N} 9\right)$ outbreak, infection with the virus has resulted in severe and fatal respiratory disease $[2,4]$ - the first time human infections have been seen for this virus [1]. The origin of the virus has been demonstrated to be associated with a reassortant event between three earlier avian influenza viruses $[1,5]$. Its genome comprises a haemagglutinin ( $\mathrm{HA}$ ) fragment from $A\left(\mathrm{H}_{7} \mathrm{~N}_{3}\right)$, a neuraminidase (NA) fragment from an earlier $A\left(\mathrm{H}_{7} \mathrm{~N}\right.$ ) virus and six internal genomic fragments from $A\left(\mathrm{H}_{9} \mathrm{~N}_{2}\right)$.

Two recent studies have provided compelling evidence that the novel $\mathrm{A}\left(\mathrm{H}_{7} \mathrm{~N}\right.$ ) $)$ viruses from patients have a close genetic relationship with isolates from poultry $[6,7]$, suggesting that the $A\left(\mathrm{H}_{7} \mathrm{~N}_{9}\right)$ virus may have spread to humans from poultry. However, preliminary epidemiological data showed that 18 of 77 confirmed cases did not have a history of contact with poultry [2]. Therefore, it remains to be determined whether there is a direct epidemiological link between exposure to poultry and human $\mathrm{A}\left(\mathrm{H}_{7} \mathrm{~N} 9\right)$ virus infection.

Huzhou city, located in northern Zhejiang Province, China, is the geographical centre of the Yangtze River Delta (Figure 1). As of 10 May, 12 confirmed $A\left(\mathrm{H}_{7} \mathrm{~N} 9\right)$ cases have been reported in Huzhou city, accounting for about $9 \%(12 / 129)$ of all cases in China. There are two natural wetlands that provide habitats for over a 160 kinds of wild birds and, until the markets were closed, there had been an active live poultry business in Huzhou city. Therefore, we performed a detailed epidemiological study of the links between the confirmed cases and prior exposure to poultry.

\section{Data collection}

A total of 12 persons were identified as influenza $\mathrm{A}\left(\mathrm{H}_{7} \mathrm{~N} 9\right)$ confirmed cases, according to the definition in the national guidelines [8]. The infection was laboratory confirmed by real-time reverse transcription-polymerase chain reaction (RT-PCR) analysis [9].

A close contact was defined as a person who came within two metres of a confirmed case without the use of effective personal protective equipment (e.g. masks and gloves) during the presumed infectious period. The close contacts included, among others, the cases' families and clinical staff (doctors and nurses) who had been in contact with the cases. All close contacts were traced and quarantined for seven days after their most recent exposure to a confirmed case. 


\section{FIGURE 1}

Distribution of the influenza A(H7N9) confirmed cases and live poultry markets in Huzhou city, China, March-May 2013

Cases $1-12$

Poultry markets visited by cases $(n=9)$

Other poultry markets nearby not visited by cases $(n=7)$

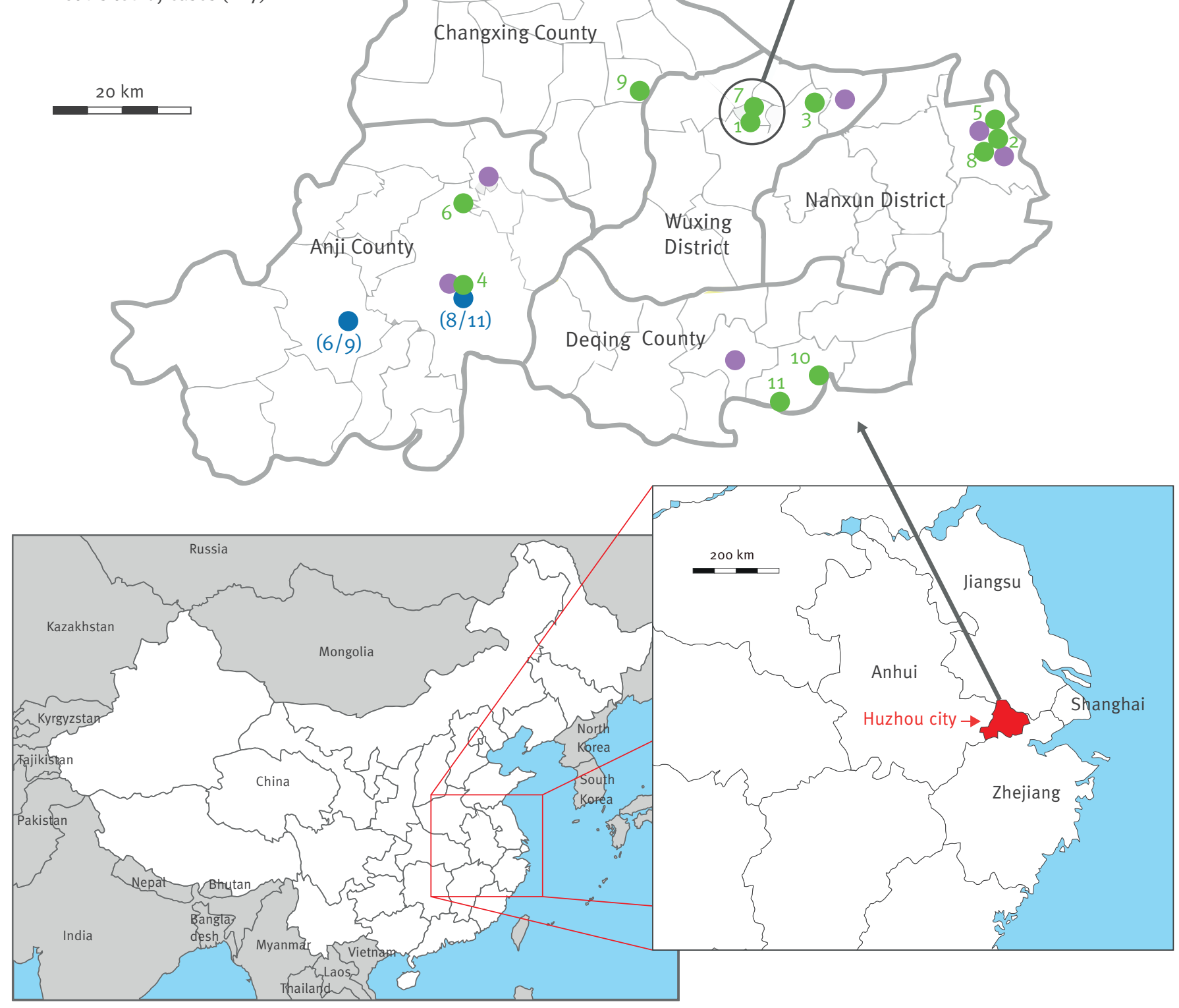

For markets that the cases did not visit, the numbers of the samples positive for influenza $\mathrm{A}\left(\mathrm{H}_{7} \mathrm{~N}\right.$ ) virus are shown (number of positive/ number of total samples). The results for the markets that the cases visited are shown in Table 1.

In our investigation, a 'visit' included only occasions in which a case either bought poultry, or had been close to (within a distance of two metres) or touched live poultry booths at the market. 
Information on cases' demographic characteristics, dates of symptom onset, exposure to poultry and/or other animals and/or visits to a live poultry market during the 10 days before symptom onset, as well as clinical signs and symptoms were collected using a standardised questionnaire and an open interview with the cases or their relatives when the cases were admitted to hospital. In our investigation, a 'visit' included only occasions in which a case either bought poultry, or had been close to or touched live poultry booths at a market.

To determine the source of the influenza $\mathrm{A}\left(\mathrm{H}_{7} \mathrm{~N} 9\right)$ virus, we collected poultry faeces, waste (swab samples from culling benches) and sewage from the nine live poultry markets visited by the cases, for detection of $A\left(\mathrm{H}_{7} \mathrm{Ng}\right)$ viral RNA by real-time RT-PCR.

In addition, samples from several surrounding live poultry markets $(n=7)$ not visited by cases were also collected.

\section{Data analysis}

Demographic and clinical characteristics of influenza $A(H 7 N 9)$ cases in Huzhou city As of 10 May 2013, 12 influenza $A\left(\mathrm{H}_{7} \mathrm{~N}\right.$ ) ) cases (four were male and eight female) were confirmed in Huzhou city (Table 1). As of 30 April, two had died, four had recovered fully, two were recovering and the other four remained critically ill (Figure 2). The median age was 60 years (range: $32-81$ ) and most $(n=9)$ were aged over 50 years.

The first case developed symptoms on 29 March 2013; the infection was laboratory confirmed on 4 April [6]. In fact, another patient (Case 2) became ill earlier, on 12 March, but the infection was not laboratory confirmed until 8 April. The last two patients (Cases 11 and 12) both became ill on 17 April and were laboratory confirmed on 25 and 26 April, respectively. The initial symptoms were fever (axillary temperature greater than $\left.37.5^{\circ} \mathrm{C}\right)(n=7)$, cough $(n=4)$, myalgia $(n=4)$, chills

TABLE 1

Demographic and exposure information of influenza A(H7N9) confirmed cases in Huzhou city, China, March-May 2013 $(\mathrm{n}=12)$

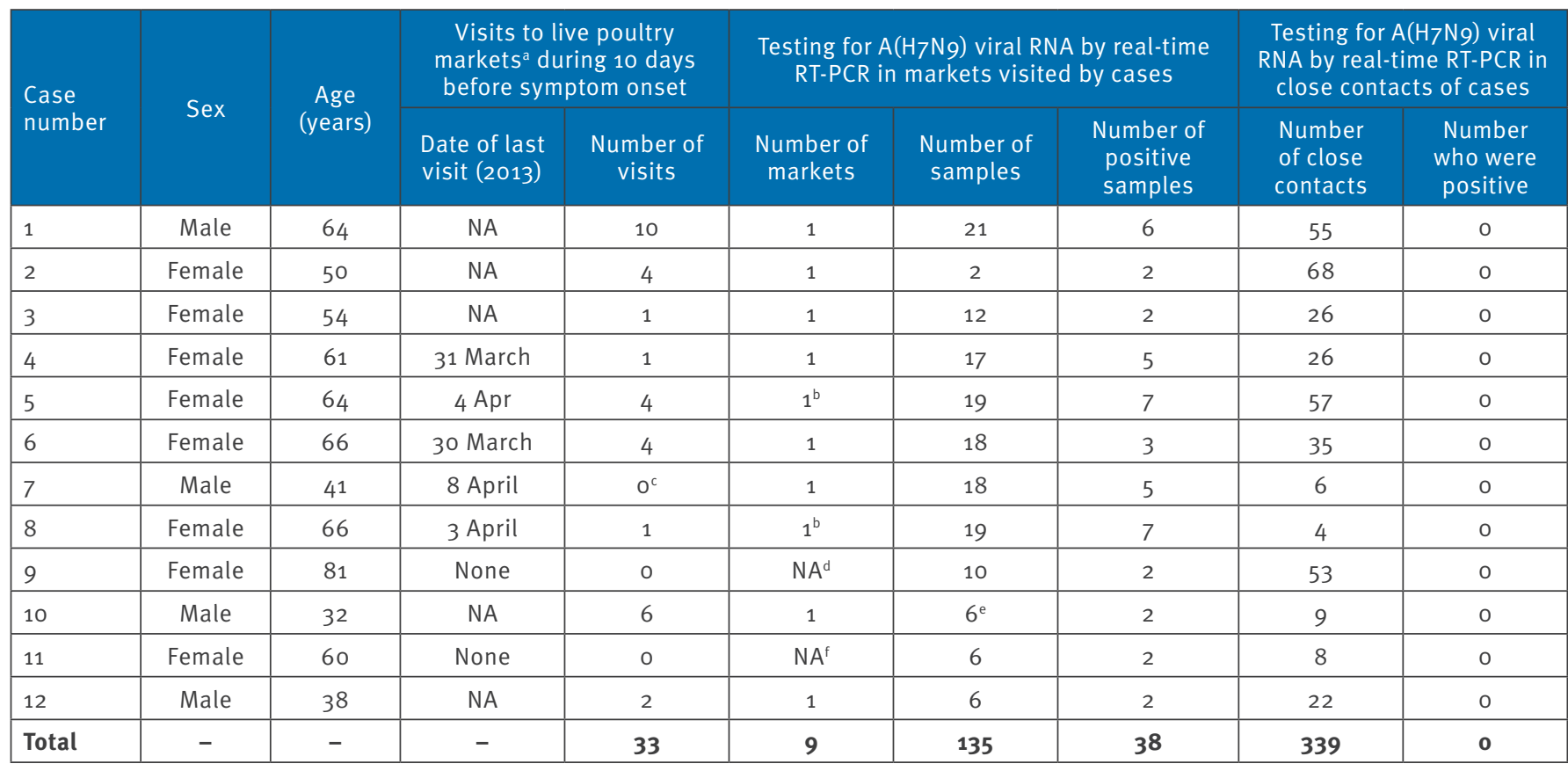

NA: not available; RT-PCR: reverse transcription-polymerase chain reaction.

a In our investigation, a 'visit' included only occasions in which a case either bought poultry, or had been close to (within a distance of two metres) or touched live poultry booths at a market.

b Cases 5 and 8 visited, on separate occasions, the same live poultry market.

Although this case did not purchase poultry, he took part in a government campaign of culling poultry at a live poultry market to limit the transmission of the novel influenza $\mathrm{A}\left(\mathrm{H}_{7} \mathrm{N9}\right)$ virus, for about three hours on 8 April 2013.

d This case did not visit a live poultry market. She raised chickens in a courtyard with her neighbour. Because the case slaughtered all her chickens, we collected 10 samples from five chickens raised by her neighbour.

Pigeon-related samples. All other samples in the study were chicken-related samples.

f The case's husband purchased four live chickens from a market on 8 April 2013 and raised them at home. On 10 April, because the chickens developed an acute illness, the case gave them antibiotics. We collected chicken faeces from her house. 

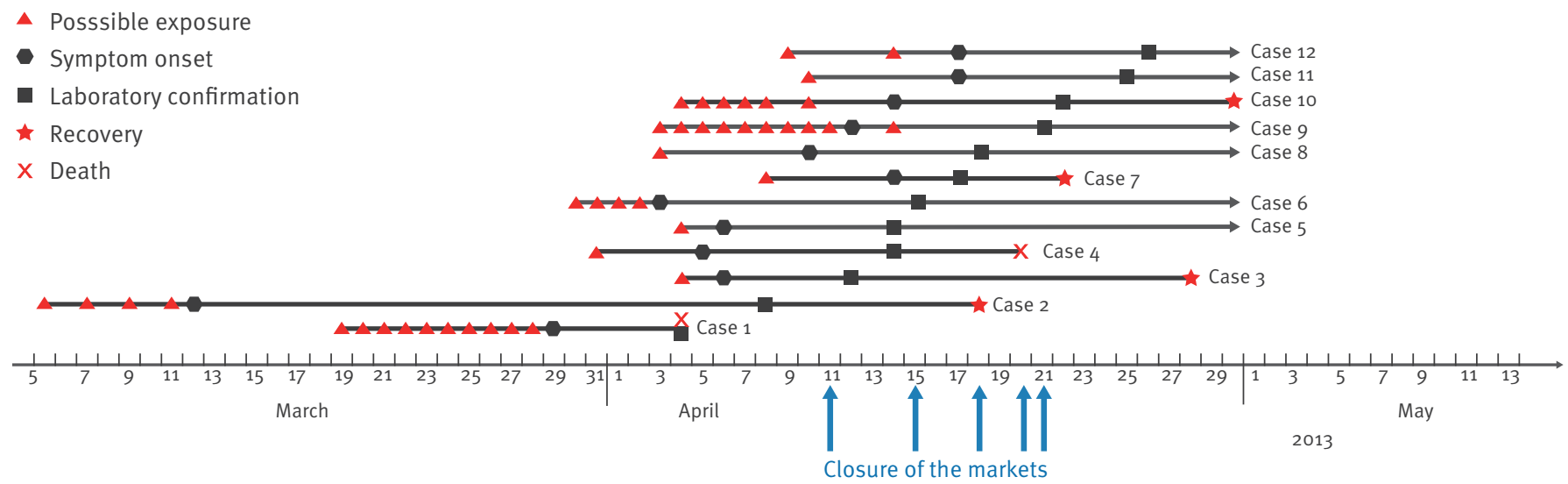

$(n=2)$, weakness $(n=2)$, nasal obstruction and runny nose $(n=1)$, expectoration $(n=1)$, pruritic body rash $(n=1)$, chest tightness $(n=1)$ and nausea $(n=1)$. Of the 12 cases, nine developed severe pneumonia and pulmonary dysfunction 2-10 days after symptom onset.

Of the 12 cases, 10 had chronic underlying conditions such as hypertension, bronchitis or heart disease, before infection. Three cases had low counts of white blood cells (between $1.7 \times 10^{9} / \mathrm{L}$ and $3.5 \times 10^{9} / \mathrm{L}$ ); in another two, the count was high $\left(12.7 \times 10^{9} / \mathrm{L}\right.$ and 13.4 $\times 10^{9} / \mathrm{L}$ ), while the others were within the normal reference range $\left(4-10 \times 10^{9} / \mathrm{L}\right)$. All but one case (with 3.4 $\mathrm{mg} / \mathrm{L}$ ) had high levels of high-sensitivity C-reactive protein (between $18.4 \mathrm{mg} / \mathrm{L}$ and $>200 \mathrm{mg} / \mathrm{L}$ (i.e. exceeding the detection range); normal reference range: $0-10$ $\mathrm{mg} / \mathrm{L})$.

\section{All cases had a history of exposure to poultry before symptom onset}

Nine of the 12 cases had visited nearby live poultry markets at least once (range: 1-10 times) during the 10 days before symptom onset (Table 1 ). Of these nine cases, four (Cases 4, 5, 6, and 8) had had direct contact with live poultry during this time. Although three patients had not visited poultry markets, they all had a history of direct contact with live poultry during the 10 days before symptom onset. Case 7 was exposed to live poultry as part of a government campaign to cull poultry at live poultry markets. Case 9 and her neighbour had purchased 12 chickens from a chicken vendor and had raised them in the same courtyard for about 20 days. Case 9 killed her seven chickens when she found that one of them had become ill. For Case 11, her husband purchased four live chickens from a market on 8 April and raised them at home. On 10 April, because the chickens developed an acute illness, the patient gave them antibiotics.
Influenza A(H7N9) viral RNA was detected in all poultry markets visited by cases In total, nine live poultry markets were epidemiologically associated with the patients (Table 1, Figure 1). Therefore, we collected poultry faeces, waste and sewage from these markets, to test for the presence of $A\left(\mathrm{H}_{7} \mathrm{~N} 9\right)$ viral RNA. We also collected throat and anal swabs and faeces from the chickens raised by the neighbour of Case 9 and chicken faeces from the house of Case 11. Of the 135 samples obtained, 38 samples were positive. Of particular note, $\mathrm{A}\left(\mathrm{H}_{7} \mathrm{~N} 9\right)$ viral RNA was detected in samples from all nine markets, as well as those from the courtyard of Case 9 and the house of Case 11.

In addition, we expanded our surveillance to seven other nearby live poultry markets that the cases had not visited. Of 75 samples tested, 23 were positive for $\mathrm{A}\left(\mathrm{H}_{7} \mathrm{~N} 9\right)$ viral RNA.

We also collected throat swabs from the close contacts $(n=339)$ of the 12 patients. Among 339 samples, none tested positive for $\mathrm{A}\left(\mathrm{H}_{7} \mathrm{~N} 9\right)$ viral RNA, indicating no human-to-human transmission of the virus.

\section{Discussion}

Previous studies have suggested that several mutations in the $\mathrm{HA}$ might be involved in the acquisition of the ability of the $A\left(\mathrm{H}_{7} \mathrm{~N} 9\right)$ virus to infect humans $[5-7,10]$, and genetic evidence indicates that poultry is the reservoir of the virus $[6,7]$. However, preliminary observations that not all patients have had a history of exposure to poultry raise the controversial issue of the source and transmission route of the $A\left(\mathrm{H}_{7} \mathrm{~N} 9\right)$ virus [2].

Our results provide epidemiological evidence to support the hypothesis that $\mathrm{A}\left(\mathrm{H}_{7} \mathrm{~N} 9\right)$ virus-infected poultry are a transmission source. A total of 139 live poultry 
Effect of closure of live poultry markets in the five regions of Huzhou city, China, March-May 2013

\begin{tabular}{|c|c|c|c|c|c|c|}
\hline \multirow{2}{*}{ Region } & \multicolumn{2}{|c|}{ Date of symptom onset (2013) } & \multirow{2}{*}{$\begin{array}{l}\text { Date of market } \\
\text { closure (2013) }\end{array}$} & \multirow{2}{*}{$\begin{array}{l}\text { Number of } \\
\text { markets closed }\end{array}$} & \multicolumn{2}{|c|}{ Number of confirmed influenza $\mathrm{A}\left(\mathrm{H}_{7} \mathrm{~N} 9\right)$ cases $^{\mathrm{a}}$} \\
\hline & First case & Last case & & & Before market closure & After market closure \\
\hline Wuxing District & 29 March & 14 April & 11 April & 32 & 3 & o \\
\hline Nanxun District & 12 March & 10 April & 15 April & 30 & 3 & 0 \\
\hline Deqing County & 14 April & 17 April & 21 April & 19 & 2 & o \\
\hline $\begin{array}{l}\text { Changxing } \\
\text { County }\end{array}$ & 12 April & 17 April & 20 April & 38 & 2 & 0 \\
\hline Anji County & 3 April & 15 April & 18 April & 20 & 2 & 0 \\
\hline Total & - & - & - & 139 & 12 & 0 \\
\hline
\end{tabular}

In order to exclude people who were infected by the virus but did not develop symptoms before market closure, case numbers were counted seven days after closure of the corresponding market.

markets (including those tested) in the five districts or counties in Huzhou city were closed sequentially, from 11 April to 21 April (Table 2). As of 15 May, no new cases have been identified in Huzhou city ( $p<0.01$ ). Although based on small case numbers, our findings support the view that poultry are a crucial transmission source and also indicate that closing live poultry markets in affected areas is an effective strategy to stop the outbreak.

With respect to the absence of reported poultry exposures in some patients $(n=18)$ in a previous study [2], we can suggest two possible explanations, arising from our findings: (i) some patients may have forgotten some details of their exposure history by the time the epidemiological investigation was carried out; or (ii) some patients may have been unable to provide timely and reliable information due to their serious clinical conditions. It may therefore be possible that patients with no documented exposure may have in fact been exposed to poultry.

We tested 339 throat swabs from the cases' close contacts, but none tested positive for the $\mathrm{A}\left(\mathrm{H}_{7} \mathrm{~N} 9\right)$ viral RNA, suggesting that these patients did not spread the virus to their close contacts. Although throat swabs may not be as often positive as deep sputum samples $[7,11]$, we did not collect sputum samples from these close contacts because they had no obvious symptoms. Most patients $(n=9)$ were aged 50 years or older, consistent with the nationwide data (78/107) [4]. Distinct from the nationwide data, however, two thirds (8/12) of the cases in Huzhou city were female (nationwide data: 32/106). This could possibly be due to the fact that in Huzhou city, housewives are mainly responsible for buying food, such as meat or vegetables, in local markets. It should also be borne in mind that most of the cases $(n=10)$ had chronic underlying conditions.
Whether an individual's health status is associated with susceptibility to $\mathrm{A}\left(\mathrm{H}_{7} \mathrm{~N} 9\right)$ virus infection remains to be proved.

Although an earlier study found that some live poultry markets tested positive, only a few poultry vendors $(n=4)$ were found to be infected with the virus [2]. Why most vendors remained infection-free despite extremely frequent exposure to infected poultry is also unclear. Whether there is some pre-existing crossreactive immunity, which enhances the susceptibility of patients to $\mathrm{A}\left(\mathrm{H}_{7} \mathrm{~N} 9\right)$ virus infection [4] or prevents poultry vendors from infection needs to be determined.

\section{Acknowledgements}

This work was supported by grants from the China National Mega-projects for Infectious Diseases (2012ZX10004211002 and 2013ZX10004101-005) to KL and the Li Ka-Shing Foundation to QL.

\section{Authors' contributions}

$\mathrm{KL}, \mathrm{CZ}$, JH and MJ designed and supervised the study. JH, PZ, MJ, JL, LW, DW, GL, XL, YZ, XD, BS, and SG performed the epidemiological investigation, sample collection, and laboratory confirmation of $\mathrm{H}_{7} \mathrm{~N} 9$ infection. $\mathrm{KL}, \mathrm{CZ}, \mathrm{JH}, \mathrm{QL}$ and $\mathrm{MJ}$ analysed and discussed the results. $C Z$ wrote the paper, and $\mathrm{KL}$ and QL revised the paper. All authors have seen and approved the final version.

Conflict of interest

None declared. 


\section{References}

1. Gao R, Cao B, Hu Y, Feng Z, Wang D, Hu W, et al. Human infection with a novel avian-origin influenza $A\left(\mathrm{H}_{7} \mathrm{~N} 9\right)$ virus. $\mathrm{N}$ Engl J Med. 2013 Apr 11. [Epub ahead of print].

2. Li Q, Zhou L, Zhou M, Chen Z, Li F, Wu H, et al. Preliminary report: epidemiology of the avian influenza $A\left(\mathrm{H}_{7} \mathrm{Ng}\right)$ outbreak in China. N Engl J Med. 2013 Apr 24. [Epub ahead of print].

3. Belser JA, Bridges CB, Katz JM, Tumpey TM. Past, present, and possible future human infection with influenza virus $A$ subtype H7. Emerg Infect Dis. 2009;15(6):859-65.

http://dx.doi.org/10.3201/eid1506.090072

PMid:19523282 PMCid:2727350

4. Skowronski DM, Janjua NZ, Kwindt TL, De Serres G. Virushost interactions and the unusual age and sex distribution of human cases of influenza $A(\mathrm{H} 7 \mathrm{Ng})$ in China, April 2013. Euro Surveill. 2013;18(17):pii=20465. Available from: http://www. eurosurveillance.org/ViewArticle. aspx?Articleld $=20465$

5. Liu D, Shi W, Shi Y, Wang D, Xiao H, Li W, et al. Origin and diversity of novel avian influenza A H7N9 viruses causing human infection: phylogenetic, structural, and coalescent analyses. Lancet. 2013. pii: So140-6736(13)60938-1.

6. Han J, Niu F, Jin M, Wang L, Liu J, Zhang P, et al. Clinical presentation and sequence analyses of $\mathrm{HA}$ and NA antigens of the novel $\mathrm{H}_{7} \mathrm{~N} 9$ viruses. Emerg Microbes Infect. 2013;2:e23.

7. Chen Y, Liang W, Yang S, Wu N, Gao H, Sheng J, et al. Human infections with the emerging avian influenza $\mathrm{A} \mathrm{H} 7 \mathrm{~N}$ 9 virus from wet market poultry: clinical analysis and characterisation of viral genome. Lancet. 2013. pii: S0140-6736(13)60903-4.

8. Ministry of Health $(\mathrm{MOH})$ of China. Diagnostic and treatment protocol for human infections with avian influenza $\mathrm{A}(\mathrm{H} 7 \mathrm{Ng})$. 2nd ed. Beijing: $\mathrm{MOH}$ of China; 2013. Available from: http:// www.moh.gov.cn/mohgjhzs/s7952/201304/98ceede1daf74a45 b1105f18c4e23ece.shtml

9. World Health Organization (WHO). Real-time RT-PCR protocol for the detection of avian influenza $A(H 7 N 9)$ virus. Beijing: WHO Collaborating Center for Reference and Research on Influenza at the Chinese National Influenza Center; 8 April, updated 15 April 2013. Available from: http://www.who.int/ influenza/gisrs_laboratory/cnic_realtime_rt_pcr_protocol_a h7n9.pdf

10. Kageyama T, Fujisaki S, Takashita E, Xu H, Yamada S, Uchida Y, et al. Genetic analysis of novel avian $A(\mathrm{H} 7 \mathrm{Ng})$ influenza viruses isolated from patients in China, February to April 2013. Euro Surveill. 2013;18(15):pii= 20453. Available from: http://www. eurosurveillance.org/ViewArticle. aspx?Articleld $=20453$

11. Covalciuc KA, Webb KH, Carlson CA. Comparison of four clinical specimen types for detection of influenza $A$ and $B$ viruses by optical immunoassay (FLU OIA test) and cell culture methods. J Clin Microbiol. 1999;37(12):3971-4. 